\title{
Clinical outcomes of lingual orthodontic treatment: a systematic review
}

\author{
Ilias Mistakidis*, Hattan Katib**, Georgios Vasilakos***, Dimitrios Kloukos**, \\ Nikolaos Gkantidis**
}

\begin{abstract}
*Department of Orthodontics, Faculty of Dentistry, Aristotle University of Thessaloniki GR-54124, Greece, **Department of Orthodontics and Dentofacial Orthopedics, University of Bern, Freiburgstrasse $7 \mathrm{CH}-3010$, Switzerland and ***Private Practice, Frankfurter Strasse 610, DE-51145, Cologne, Germany
\end{abstract}

Correspondence to: Nikolaos Gkantidis, Department of Orthodontics and Dentofacial Orthopedics, University of Bern, $\mathrm{CH}$ 3010, Freiburgstrasse 7, Bern, Switzerland. E-mail: nikosgant@yahoo.gr

\section{Summary}

Objectives: To assess the available evidence on the effectiveness of lingual orthodontic treatment and related clinical parameters through a systematic review of relevant studies.

Materials and methods: Eligible clinical studies published from January 2000 to March 2015 were identified through electronic (five major databases) and hand searches. Risk of bias was assessed using the Cochrane risk of bias tool for prospective studies and a specially designed tool for retrospective studies.

Results: From the 3734 articles identified by the search, after application of specific inclusion and exclusion criteria, 16 papers were included in the study. Eleven studies were retrospective, four were prospective, and only one was a RCT. In detail, six studies evaluated differences of the treatment outcome from the pre-treatment set-up prediction, two studies evaluated the effect of treatment on periodontal and microbial parameters, and 10 studies assessed various clinical treatment related parameters. Despite several promising findings, the quality of evidence supporting them was found to be low in most cases.

Conclusions: This systematic review showed encouraging results on the clinical outcome of lingual orthodontic treatment, especially in regards to the achievement of individualized treatment goals and the reduction of decalcifications on the bonded surfaces of the teeth. However, additional well-designed prospective clinical trials with larger samples are needed to confirm those findings. Several aspects of lingual orthodontic treatment were difficult to be conclusively evaluated due to the study design, the heterogeneity, the small samples sizes, and the high risk of bias seen in the majority of the included studies.

\section{Introduction}

The aesthetic demands of patients have been increased during the years regarding not only the treatment objectives, but also the influence of orthodontic appliances in patient's aesthetic appearance. Conventional orthodontic treatment has been shown to compromise facial appearance (1) and this is a major concern of patients seeking orthodontic treatment (2). As a result, aesthetic materials and techniques have been introduced in clinical practice to overcome these limitations (3).
Lingual orthodontics comprise a fundamental expression of this necessity (4). Since its introduction in 1980 s, several systems and techniques have been introduced, revealing the increased interest of patients and doctors for this treatment approach (5). The major advantage of lingual orthodontics is that the appliances are not visible. However, lingual orthodontics comprises a relatively new treatment option that has certain differences to the well-established labial orthodontic treatment, mainly attributed to the position of the appliances $(6,7)$. A recent systematic review of six studies that compared certain adverse effects of 
lingual and labial orthodontic treatment (8) provided further support to this viewpoint. Differences that may exist in various aspects of treatment, and can be related to the patient, the practitioner, or the appliance itself, might be responsible for the limited, although increasing use of lingual orthodontics in everyday practice $(5,7,9,10)$.

During the years, several case reports, reviews, and clinical research papers have discussed various aspects of lingual orthodontic treatment. However, a thorough systematic evaluation of clinical studies related to clinical outcomes of lingual orthodontic treatment is lacking from the literature. Such a review will allow gather the supporting evidence on this expanding treatment approach, will help clinicians to provide evidence-based treatment, and will provide recommendations for targeted future research in the field. Thus, the purpose of the present study is to assess the available evidence on the effectiveness of lingual orthodontic treatment and related clinical parameters through a systematic review of recent relevant studies (published later than 1 January 2000).

\section{Material and methods}

The present systematic review was conducted and reported according to the Preferred Reporting Items for Systematic reviews and Meta-Analyses (PRISMA) guidelines for reporting studies that evaluate health care interventions $(11,12)$, to the Meta-analysis of Observational Studies in Epidemiology (MOOSE) guidelines for reporting observational studies $(13,14)$, and to the Cochrane Non-Randomized Studies Methods Group (15). The Grades of Recommendation, Assessment, Development, and Evaluation (GRADE) approach (16) was used for grading the quality of evidence. A pilot Pubmed search followed by systematic evaluation of 10 potentially eligible and randomly selected studies were performed in order to draft the review protocol. Methods of search and analysis, eligibility assessment, data extraction forms, and all other methods and tools used were defined in advance of the study based on the results of the pilot study.

The main type of intervention, e.g. buccal or lingual-fixed orthodontic appliances is unlikely to be randomized, since patients usually decide about this issue based on individual needs and preferences. Furthermore, this is a relatively new and unexplored treatment, especially in terms of systematic evaluations. Thus, we decided to evaluate for eligibility also non-randomized and retrospective studies following a quality assessment protocol (see details below).

\section{Search methods for identification of studies}

Electronic search was conducted by two authors (G.V. and N.G.) in five major databases, Medline, EMBASE, Google scholar beta, all Cochrane Databases, and Conference Paper Index with the last update on March 2015. A complex Medline search (via Pubmed) was performed to identify any relevant study, based upon various combinations of key words including: 'lingual orthodontics', 'lingual patients', 'lingual brackets', in all fields (Limits: Humans, English, German, French, Italian). A detailed description of the Medline electronic search strategy is provided in supplemental Appendix 1. Similar searches were performed in all the electronic databases used for the study.

All papers assessed through full text reading, all included papers, and all reviews identified were subjected to hand search of their references for relevant papers that might have been missed during the electronic search.

Unpublished literature was searched through Cochrane Central Register of Controlled Trials, Conference Paper Index, and Google scholar.

\section{Selection of studies}

Eligibility assessment was performed in a standardized manner, independently, and in duplicate by two reviewers (H.K. and G.V.) who were not blinded to the identity of the authors, their institution, or the results of the research. Any disagreement was resolved by consensus and through discussion among all authors. Titles and abstracts were screened first and afterwards full text review of any relevant and potential for inclusion article was conducted.

A positive exclusion method was used, whereby only those publications that did not meet one or more of the inclusion criteria were excluded. An independent reviewer (I.M.) checked a random selection (20 per cent) of filtered articles for consistency. Inter-rater agreement on study eligibility was assessed by Cohen's kappa.

\section{Eligibility criteria}

The following inclusion criteria were applied:

1. Randomized clinical trials (RCTs), prospective controlled clinical trials (CCTs), or retrospective studies with a control group reporting on results or treatment parameters related to orthodontic treatment performed with fixed lingual brackets bonded at least to all teeth between first molars, in one or both arches.

2. English, German, French, and Italian languages.

The exclusion criteria were:

1. Studies reporting results emerging from questionnaires.

2. In vitro and animal studies.

3. Case reports/case series (sample size $\leq 10$ ).

4. Editorials, opinions, reviews, and technique description articles, without reported sample.

5. Studies referring to lingual treatment performed in selected teeth of an arch or combined with other appliances, such as labial brackets, in a non-defined manner and not in order to investigate a specific hypothesis under a split-mouth design.

6. Studies published prior to January 2000 were excluded to control for confounding derived from the large differences of bracket types and application techniques of that time compared with the current practice.

\section{Types of participants}

Healthy participants who require orthodontic treatment with fixed appliances with no age limit. Studies including patients receiving any kind of medication, which can influence orthodontic treatment or patients receiving orthognathic surgery, syndromic patients, patients with cleft lip and palate, or any systemic disease were excluded.

\section{Types of interventions}

Any treatment approach utilizing orthodontic fixed lingual appliances placed in one or both dental arches, used to correct any type of malocclusion, were included.

\section{Control}

Conventional orthodontic treatment with fixed labial appliances or no treatment. The planned treatment outcome and comparable patients receiving fixed appliance treatment with different lingual bracket systems or application techniques (i.e. different bonding protocols) were also considered.

\section{Types of outcome measures}

Any measure of performance or effectiveness of the intervention tested including its accuracy and any parameter regarding the quality 
of the treatment outcome, periodontal, or dental parameters (plaque index, gingival index, root resorption, tooth necrosis/loss of vitality etc.), or various clinical aspects of treatment (duration of treatment, stability of final outcome, bond failures etc.).

\section{Data extraction process}

Data extraction was performed by two authors (I.M. and H.K.), independently in the pre-determined data extraction forms that were also used for quality assessment of the included studies. In cases of inconsistencies re-examination of the original studies by the two reviewers and discussion resolved any disagreements. N.G. was responsible for checking the data extraction forms. Inter-rater agreement on data extraction was assessed by Cohen's kappa.

\section{Quality assessment of individual studies}

The quality assessment of the eligible studies was performed by two investigators, independently (D.K. and N.G.). In areas of disagreements, a joint decision was obtained after discussion between all authors in order to reach a consensus. Quality assessment of randomized studies was performed using the Cochrane Risk of bias tool (17). The same tool was also used for non-randomized prospective studies in the applicable domains.

To assess the quality of the retrospective studies, two investigators working independently (D.K. and N.G.) evaluated several items according to a modified quality assessment tool designed based on Newcastle-Ottawa scale (18), relevant guidelines of the Cochrane Handbook for Systematic Reviews of Interventions Version 5.1.0 (15), and the GRADE approach (16).

We categorized overall risk of bias in any included study according to the following.

1. Low risk of bias (plausible bias unlikely to seriously alter the results) if all key domains were assessed as at low risk of bias.

2. Unclear risk of bias (plausible bias that raises some doubt about the results) if one or more key domains were assessed as at unclear risk of bias.

3. High risk of bias (plausible bias that seriously weakens confidence in the results) if one or more key domains were assessed as at high risk of bias.

\section{Dealing with missing data}

The analysis was performed using only the available data (ignoring missing data); methods for estimating missing SDs as described in Section 7.7.3 of the Cochrane Handbook for Systematic Reviews of Interventions (15), were used where applicable.

\section{Data synthesis}

A meta-analysis was planned only if there were at least two studies of similar comparisons, reporting similar outcome at similar time points. For qualitative synthesis, the included studies were to be assigned to general groups according to their subject category.

\section{Determination of available evidence supporting clinical recommendations}

Following the quality assessment of individual articles, each one was assigned to a group according to the studied subject. For each subject, the overall quality of the body of evidence was determined after considering the quality (assessment of individual studies), quantity (magnitude of treatment effect, number of studies, sample size across studies), and consistency (the extent of similarity of different studies in their findings) of the available studies and their findings on the subject. Clinical recommendations were formulated based on these considerations and by balancing the desirable and undesirable consequences of each intervention.

\section{Results}

\section{Literature flow}

The initial electronic search yielded 3734 studies. After reading titles, abstracts, and application of inclusion and exclusion criteria, 87 studies were examined in their full-text forms. From these, 16 studies were deemed eligible for inclusion in the review and for qualitative and/or quantitative synthesis $(6,18-32)$. The flow chart of study selection together with reasons for exclusion is provided in Figure 1. The kappa scores for the initial selection and data extraction procedures were 0.86 and 0.91 , respectively.

\section{Characteristics of included studies}

The 16 included studies were assigned to three general groups according to the main outcome tested: 1 . accuracy of treatment prediction, 2. periodontal parameters, and 3. other clinical parameters. Two included studies were assigned in two groups.

Eleven studies were retrospective, four were prospective CCTs and one was RCT. Six retrospective studies tested the accuracy of lingual treatment through the comparison of set-ups with actual treatment outcome $(19-23,29)$. One of them also tested the occlusal outcome of lingual treatment compared with labial treatment (23). Ten studies tested various clinical aspects of treatment, such as effectiveness, bond failures, formation of white spot lesions, anchorage loss, and treatment duration $(6,18,22-25,28,30-32)$. Finally, two prospective CCTs assessed treatment effects on various periodontal parameters, such as the plaque index and the gingival index $(26,27)$. An overview of the characteristics of the included studies is provided in Table 1.

\section{Publication bias}

Statistical analysis of publication bias was not indicated, since no quantitative synthesis was undertaken.

\section{Risk of bias of included studies}

For non-randomized prospective CCT studies, the items of random sequence generation and allocation concealment were not applicable and were set by default as unclear. This decision was based on the specific characteristics of the clinical question studied; primarily the inability of personnel to assign patients in groups and/or predict favourable versus unfavourable outcomes. Initial inter-rater disagreement existed in 3 out of 16 cases (agreement greater than 80 per cent) and these were all between unclear and high risk ratings. Disagreements were resolved through discussion by all authors until consensus was reached.

\section{RCTs}

Only one RCT was included and was assessed as unclear overall risk of bias (6). Figure 2 shows the summary of risk of bias assessment for the RCT study according to the Cochrane Risk of bias tool.

\section{Prospective CCTs}

From the four CCTs included, two were assessed as unclear (26, $27)$ and two as high overall risk of bias $(25,30)$. Figure 2 shows the summary of risk of bias assessment for non-randomized prospective CCTs. 


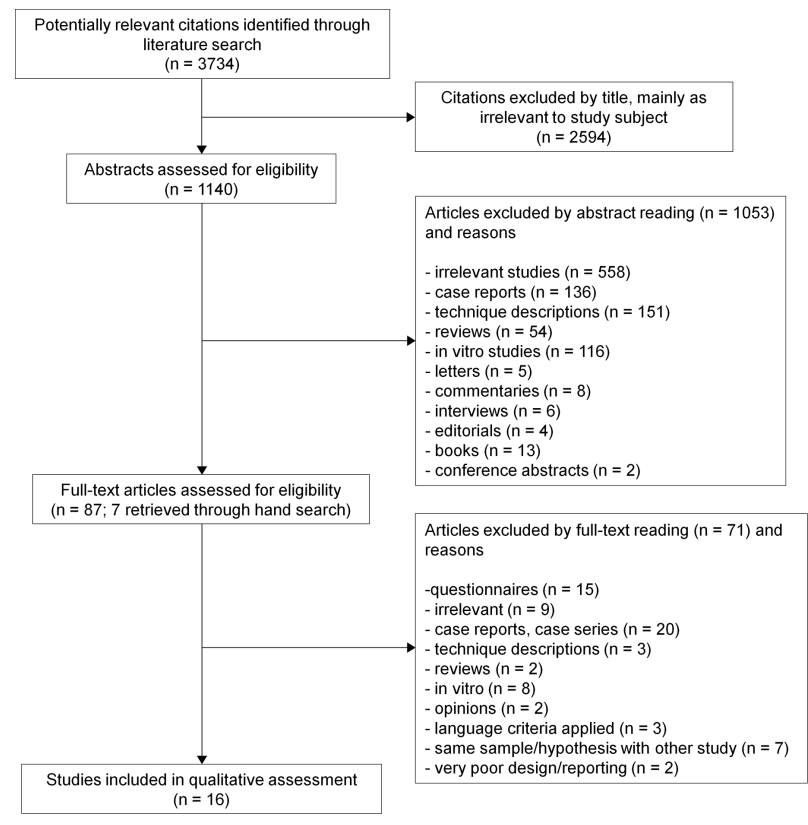

Figure 1. Flow chart of study selection.

\section{Retrospective studies}

From the 11 retrospective studies included, 10 were assessed as high $(18,20-24,28,29,31,32)$ and 1 as unclear overall risk of bias (19). Table 3 shows the assessment of risk of bias for retrospective studies.

\section{Qualitative synthesis of included studies}

A meta-analysis was not feasible since there were no studies of similar comparisons, reporting similar outcomes at similar time points. In order to proceed to the qualitative analysis, the 16 studies were divided into three main groups according to the aspect of lingual treatment tested. The aforementioned categorization did not derive from any established methodological background, but was implemented based on clinical interest. Furthermore, there is a variety of outcome measures reported in each study that does not allow in most cases for standardized reporting of results. An overview of the set-up, the findings, and the overall risk of bias assessment of individual studies is provided in Tables 1 and 2 .

\section{Effects of interventions}

Accuracy testing

In total, six studies tested the accuracy of lingual orthodontic treatment. All utilized a retrospective study design and tested the Incognito System (3M Unitek, Monrovia, California, USA) (19-23, 29). Five of them had high $(20-23,29)$ and one unclear risk of bias (19) (Table 3). Two studies $(19,20)$ assessed the deviations in tooth position between the planned (setup) and the actual treatment outcome measured on threedimensional (3D) digital dental casts. Both agreed that in most cases anterior teeth were positioned within $1 \mathrm{~mm}$ and within 4 degrees of their planned positions, whereas differences increased from anterior to posterior, with the second molars showing the poorest results. Another study tested the deviations in lower intercanine distance between the predicted (setup) and the actual outcome measured on 3D digital dental casts and reported a difference of 0.44 (SD: 0.29) mm (21). A study that tested the deviations in lower incisor inclination between the planned (setup) and the actual outcome in Class III patients reported a difference of 3.75 degrees (SD: 3.06 degrees) (29). This difference was increasing in extraction cases and when undersized finishing wires were placed.

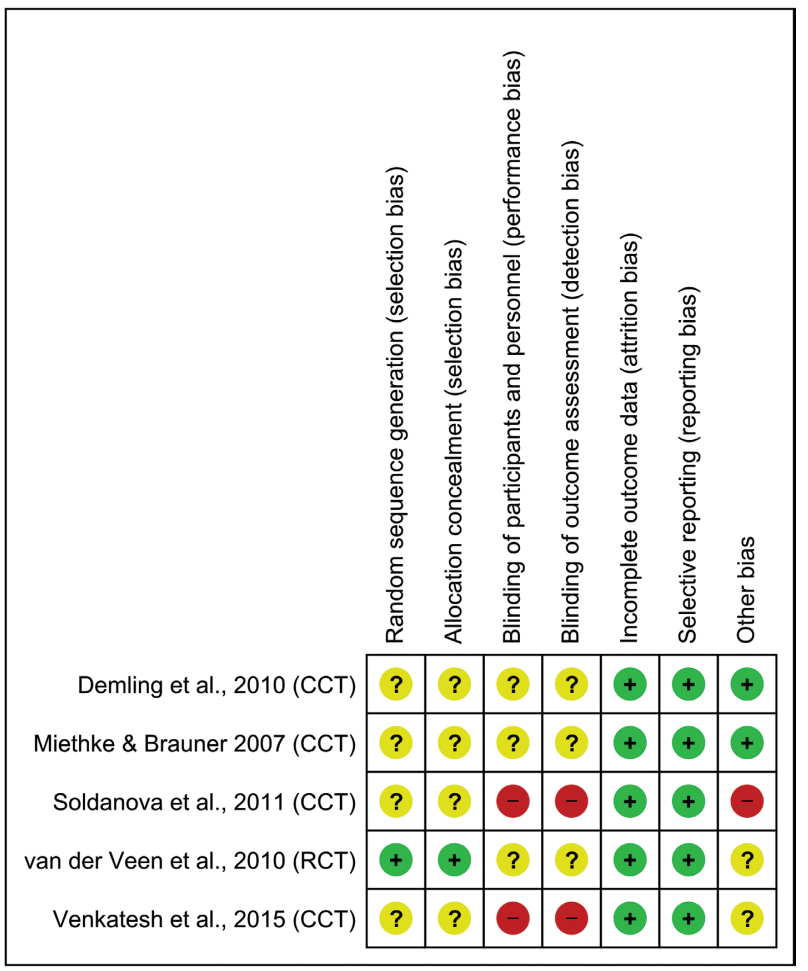

Figure 2. Risk of bias summary for included RCT and prospective CCT studies. The plus sign indicates low risk of bias; the circle with question mark indicates unclear risk of bias; the minus sign indicates high risk of bias. Overall, studies with at least one high are considered high risk of bias, studies with at least one question mark unclear risk of bias, while studies with plus signs only low risk of bias. For CCTs, the first two items are not applicable (default: unclear).

Central incisor apices also tended to move at the lingual side of the symphysis during incisor decompensation. One study tested the accuracy of the Incognito lingual technique + Herbst on mandibular incisor proclination and reported a difference between planned and final incisor positions of 2.2 degrees (SD: 1.0 degrees) $(P>0.05)(22)$. Finally, one study tested the deviations in peer assessment rating (PAR) scores measured on dental casts between the setup and the actual lingual treatment outcome and reported a difference of 4.1 in total weighted PAR score $(P<0.05)(23)$.

\section{Clinical parameters testing}

In total, 10 studies tested various clinical aspects of treatment, such as effectiveness, bond failures, formation of white spot lesions, anchorage loss, or treatment duration. Nine of them had high $(18,22-25,28,30-32)$ and one unclear risk of bias (6) (Table 3; Figure 2). A retrospective study on the effect of the Incognito lingual technique + Herbst reported a change in mandibular incisor inclination of -16.5 degrees to 5.8 degrees that was according the planned movement in each case (22). Another retrospective study compared the occlusal outcome and treatment duration with lingual (Incognito) and labial appliances and did not report any significant difference $(P>0.05)$, although there was a tendency for higher improvement in weighted PAR index through labial treatment (23). One retrospective study tested potential differences in anchorage loss in premolar extraction cases between lingual bidimensional preadjusted brackets (Ormco Corp, Glendora, California, USA) and labial appliances and reported almost double amount of anchorage loss in labial treatment (24). The same issue 
was tested in a prospective CCT study that used another bracket system (STb, Ormco, Orange, California, USA) and yielded similar results (30). A prospective study tested changes in the lower dental arch of Class I patients with crowding following orthodontic therapy with labial or lingual two-dimensional (2D) technique (Forestadent, St Louis, Missouri, USA). The only significant difference regarded the position of incisors relative to A-Po (lingual: $1.0, \mathrm{SD}: 0.5 \mathrm{~mm}$; labial: $0.0, \mathrm{SD}: 1.5 \mathrm{~mm}, P<0.05)(25)$. The only included RCT study tested the development of white spot lesions during lingual (Incognito) and labial appliance treatment. This study utilized a split mouth design and was characterized as unclear risk of bias mainly because blinding was not possible and this might have resulted to performance bias. The study concluded that the number of buccal caries that formed or progressed during treatment was 4.8 times higher than the number of lingual lesions $(P=0.01)$. Furthermore, there was an overall increase in caries extent/total lesion area that was more for buccal surfaces in a subject than for lingual surfaces $(P<0.05)(6)$. Another retrospective study from the same research group tested the effect of the addition of an extra layer of a hydrophilic resin, during bonding in the incidence of demineralization beneath the base of lingual brackets (Incognito). The addition of hydrophilic resin induced a 3-fold decrease in demineralization incidence after treatment (28). A retrospective study compared treatment with lingual ( $\mathrm{STb}$, Ormco) and labial appliances and found similar PAR reduction, treatment duration and root resorption with both techniques. The only difference was detected on post-treatment interincisal angle which was increased more by lingual treatment (T0-T1, labial: 11.2 degrees, SD: 11.6 degrees; lingual, 17.9 degrees, SD: 8.9 degrees, $P<0.05$ ) (31). In another retrospective study, the number of lost brackets during the first year of treatment was found to be similar in lingual (Incognito) and labial treatment (32). Finally, a recent retrospective study showed that treatment duration was significantly smaller with one lingual bracket system (WIN; S1: $17.96 \mathrm{~m}, \mathrm{~S} 2: 20.49 \mathrm{~m}$ ) compared to another (Incognito; S1: $22.7 \mathrm{~m}, \mathrm{~S} 2: 29.79 \mathrm{~m}$ ) (18).

\section{Periodontal parameters testing}

Two prospective CCTs with unclear risk of bias assessed treatment effects on various periodontal parameters $(26,27)$. One split-mouth study tested clinical periodontal and microbial indices before and 4 weeks after bonding of Incognito lingual appliances. Plaque index and bleeding on probing significantly increased in this period in the bonded sites, while no difference was detected for probing depth. Periodontopathogenic bacteria did not change significantly (26). The other study assessed clinical periodontal parameters after at least 6 months on treatment, at three consecutive appointments (3-4 week interval), in patients treated with Ormco seventh generation lingual (Ormco Europe, Amersfoort, The Netherlands) or Invisalign appliances. All the indices apart from probing depth improved significantly between the first and third assessments in the Invisalign patients, while they were significantly worse in lingual treatment in all time points (27).

\section{Discussion}

The growing interest of the scientific community for lingual orthodontics over the years is evident by the increasing number of relevant publications in the literature. The search of the present systematic review covered a period of 15 years (2000-2015) and 13 out of the 16 included studies were published in the last 5 years. This underlines the need for orthodontics to meet the increased aesthetic demands expressed by patients (33). However, lingual orthodontic treatment is still not considered a conventional option with widespread use in current orthodontic practice. Possible explanations for this could be the relatively unexplored clinical performance of the technique, the additional knowledge required to be applied, the fact that lingual orthodontics are not taught in the majority of postgraduate programs at the same extent as conventional buccal techniques, as well as the higher costs that are usually involved.

We decided to include only recent studies (from January 2000 and on) by applying time restriction to the search strategy in an attempt to be compatible with current clinical conditions. Otherwise, if older studies were included, the evolution of lingual appliances and techniques over the years $(34,35)$ could give results not applicable to the present clinical practice. The earliest included study was published in 2003 and the remaining studies were published after 2007.

The 16 included comparative studies were divided in three major groups according to the study subject. These regarded 1. accuracy, 2. clinical parameters, and 3. periodontal parameters testing.

In the first group, six retrospective studies tested the accuracy of lingual orthodontic treatment by comparing the planned treatment goal in the setup with the actual outcome obtained after treatment (19-23, 29). The results of these studies were encouraging, indicating that modern lingual orthodontic systems can achieve to a significant extent the individualized treatment goals established by the setup. The retrospective nature of all these studies, however, does not allow for elucidating the parameters that influence the achievement of the planned treatment outcome for the individual patient. For this, welldesigned prospective clinical trials are necessary.

The second subject group included 10 studies that investigated various clinical aspects of lingual orthodontic treatment. The only available RCT showed that the number of buccal caries lesions that formed or progressed during buccal fixed appliance treatment was approximately five times higher than the number of lingual caries lesions in lingual treatment (6). However, since blinding was not possible because of the split-mouth study design, performance bias during the study period cannot be excluded. Because of the high importance of the results of this study for the dental health, additional RCTs with large samples are needed to confirm this positive effect of lingual appliance treatment. In another retrospective study, it was found that the incidence of demineralization under the lingual bracket base was considerably reduced in children and adolescents through the addition of hydrophilic resin during the bonding procedure (28).

The other studies in the second subject group investigated various issues including effectiveness, treatment duration, anchorage loss, and bond failures. A retrospective study tested in a small group of patients the effect of lingual technique + Herbst on mandibular incisor proclination and concluded that the incisors are positioned according to the planned movement (22). Another retrospective study reported similar occlusal outcome and treatment duration with lingual (Incognito) and labial appliances (23). Two studies tested differences in anchorage loss in premolar extraction cases between lingual (STb or bidimensional, Ormco) and labial appliances and reported almost double amount of anchorage loss in labial treatment $(24,30)$. One prospective study found that labial and lingual (Forestadent) 2D treatment induces in most cases similar changes to the lower dental arch in Class I patients with crowding (25). A retrospective study concluded that treatment with lingual $(\mathrm{STb})$ and labial appliances result in similar PAR reduction, treatment duration, and root resorption (31). In another study, the number of lost brackets during the first year of treatment was found to be similar for lingual and labial appliances (32). Finally, a recent retrospective study compared two different lingual systems and showed that treatment 
Table 1. Characteristics of included studies grouped according to their main subject: (a) accuracy testing, (b) various clinical aspects testing, and (c) periodontal parameters testing.

\begin{tabular}{|c|c|c|c|c|c|c|c|}
\hline Study & Subject group & Main objective & $\begin{array}{l}\text { Place of sample } \\
\text { collection }\end{array}$ & Study design & $\begin{array}{l}\text { Treatments tested } \\
\text { and sample size }\end{array}$ & $\begin{array}{l}\text { Method of } \\
\text { sample recruit- } \\
\text { ment }\end{array}$ & $\begin{array}{l}\text { Main type of col- } \\
\text { lected data }\end{array}$ \\
\hline $\begin{array}{l}\text { Grauer and Proffit, } \\
\text { Am J Orthod } \\
\text { Dentofacial } \\
\text { Orthop } 2011 \text { (19) }\end{array}$ & Accuracy & $\begin{array}{l}\text { Accuracy of } \\
\text { Incognito lingual } \\
\text { orthodontic tech- } \\
\text { nique }\end{array}$ & $\begin{array}{l}\text { Bad Essen, Ger- } \\
\text { many }\end{array}$ & $\begin{array}{l}\text { Retrospective } \\
\text { case series }\end{array}$ & $\begin{array}{l}\text { Incognito } \\
\text { lingual treatment } \\
(n=94)\end{array}$ & $\begin{array}{l}\text { Consecutive } \\
\text { patients } \\
\text { debonded be- } \\
\text { tween } \\
\text { January } 2008 \\
\text { and January } \\
2009\end{array}$ & $\begin{array}{l}\text { Tooth position in } \\
\text { the setup and ac- } \\
\text { tual outcome meas- } \\
\text { ured at scanned } \\
\text { dental casts }\end{array}$ \\
\hline $\begin{array}{l}\text { Pauls AH, J Oro- } \\
\text { fac Orthop } 2010 \\
(20)\end{array}$ & Accuracy & $\begin{array}{l}\text { Accuracy of } \\
\text { Incognito lingual } \\
\text { orthodontic } \\
\text { technique }\end{array}$ & $\begin{array}{l}\text { Bad Essen, Ger- } \\
\text { many }\end{array}$ & $\begin{array}{l}\text { Retrospective } \\
\text { case series }\end{array}$ & $\begin{array}{l}\text { Incognito } \\
\text { lingual treatment } \\
(n=25)\end{array}$ & $\begin{array}{l}\text { Selection based } \\
\text { on specific } \\
\text { criteria }\end{array}$ & As above \\
\hline $\begin{array}{l}\text { Thalheim and } \\
\text { Swestka-Polly, Inf } \\
\text { Orthod Kiefer- } \\
\text { orthop } 2008 \text { (21) }\end{array}$ & Accuracy & $\begin{array}{l}\text { Accuracy of } \\
\text { Incognito lingual } \\
\text { orthodontic } \\
\text { technique }\end{array}$ & $\begin{array}{l}\text { Bad Essen, Ger- } \\
\text { many }\end{array}$ & $\begin{array}{l}\text { Retrospective } \\
\text { case series }\end{array}$ & $\begin{array}{l}\text { Incognito } \\
\text { lingual treatment } \\
(n=20)\end{array}$ & $\begin{array}{l}\text { Selection based } \\
\text { on specific } \\
\text { criteria }\end{array}$ & $\begin{array}{l}\text { Lower intercanine } \\
\text { distance in the } \\
\text { setup and actual } \\
\text { outcome measured } \\
\text { at scanned dental } \\
\text { casts }\end{array}$ \\
\hline $\begin{array}{l}\text { Lossdörfer et al., } \\
\text { J Orofac Orthop } \\
2013(29)\end{array}$ & Accuracy & $\begin{array}{l}\text { Accuracy of } \\
\text { Incognito } \\
\text { lingual orthodon- } \\
\text { tic technique }\end{array}$ & $\begin{array}{l}\text { Bad Essen, Ger- } \\
\text { many }\end{array}$ & $\begin{array}{l}\text { Retrospective } \\
\text { case series }\end{array}$ & $\begin{array}{l}\text { Incognito } \\
\text { lingual treatment } \\
(n=34)\end{array}$ & $\begin{array}{l}\text { Selection based } \\
\text { on specific } \\
\text { criteria }\end{array}$ & $\begin{array}{l}\text { Lower incisor } \\
\text { inclination in the } \\
\text { setup and actual } \\
\text { outcome measured } \\
\text { at scanned dental } \\
\text { casts superim- } \\
\text { posed into cepha- } \\
\text { lograms }\end{array}$ \\
\hline $\begin{array}{l}\text { Wiechmann et al., } \\
\text { Head Face Med } \\
2010(22)\end{array}$ & $\begin{array}{l}\text { Accuracy and } \\
\text { clinical }\end{array}$ & $\begin{array}{l}\text { Effect of the } \\
\text { Incognito lingual } \\
\text { technique + } \\
\text { Herbst on man- } \\
\text { dibular incisor } \\
\text { proclination }\end{array}$ & $\begin{array}{l}\text { Bad Essen, Ger- } \\
\text { many }\end{array}$ & $\begin{array}{l}\text { Retrospective } \\
\text { case series }\end{array}$ & $\begin{array}{l}\text { lingual } \\
\text { treatment }+ \\
\text { Herbst }(n=12)\end{array}$ & $\begin{array}{l}\text { Selection based } \\
\text { on specific } \\
\text { criteria }\end{array}$ & $\begin{array}{l}\text { Lower incisor posi- } \\
\text { tion before treat- } \\
\text { ment, in the setup } \\
\text { and after treatment, } \\
\text { measured at } \\
\text { scanned dental casts }\end{array}$ \\
\hline $\begin{array}{l}\text { Smith C, disserta- } \\
\text { tion } 2010(23)\end{array}$ & $\begin{array}{l}\text { Accuracy and } \\
\text { clinical }\end{array}$ & $\begin{array}{l}\text { Accuracy of } \\
\text { Incognito lingual } \\
\text { orthodontic } \\
\text { technique; oc- } \\
\text { clusal outcome } \\
\text { and treatment } \\
\text { duration with } \\
\text { lingual and labial } \\
\text { appliances }\end{array}$ & Illinois, USA & $\begin{array}{l}\text { Retrospective } \\
\text { case series }\end{array}$ & $\begin{array}{l}\text { Incognito } \\
\text { lingual }(n=21) \\
\text { versus various } \\
\text { labial }(n=22)\end{array}$ & $\begin{array}{l}\text { Consecutive } \\
\text { selection based } \\
\text { on specific } \\
\text { criteria }\end{array}$ & $\begin{array}{l}\text { PAR scores } \\
\text { measured in the } \\
\text { setup and actual } \\
\text { outcome (final) } \\
\text { casts for lingual } \\
\text { treatment and } \\
\text { between initial } \\
\text { and final casts for } \\
\text { both groups }\end{array}$ \\
\hline $\begin{array}{l}\text { Geron et al., } \\
\text { Angle Orthod } \\
2003(24)\end{array}$ & Clinical & $\begin{array}{l}\text { Anchorage loss } \\
\text { relative to extrac- } \\
\text { tion site (first } \\
\text { versus second } \\
\text { premolar), ap- } \\
\text { pliance (lingual } \\
\text { versus labial), age } \\
\text { (adolescents ver- } \\
\text { sus adults), overjet } \\
\text { and crowding }\end{array}$ & $\begin{array}{l}\text { Tel Aviv, Israel } \\
\text { t }\end{array}$ & $\begin{array}{l}\text { Retrospective } \\
\text { case series }\end{array}$ & $\begin{array}{l}\text { Bidimensional } \\
\text { lingual } \\
\text { (Ormco; } n=13 \text { ) } \\
\text { versus labial } \\
\text { (Victory System, } \\
\text { 3M Unitek; } \\
n=15 \text { ) }\end{array}$ & $\begin{array}{l}\text { Selection based } \\
\text { on specific } \\
\text { criteria }\end{array}$ & $\begin{array}{l}\text { Anchorage loss } \\
\text { (amount of mesial } \\
\text { movement of the } \\
\text { upper first molar) } \\
\text { measured in } \\
\text { cephalograms and } \\
\text { dental casts }\end{array}$ \\
\hline $\begin{array}{l}\text { Venkatesh et al., } \\
\text { APOS Trends } \\
\text { Orthod } 2015 \\
(30)\end{array}$ & Clinical & $\begin{array}{l}\text { Anchorage loss } \\
\text { during first pre- } \\
\text { molar extraction } \\
\text { space closure } \\
\text { with labial and } \\
\text { lingual appli- } \\
\text { ances }\end{array}$ & Karnataka, India & $\begin{array}{l}\text { Prospective } \\
\text { CCT }\end{array}$ & $\begin{array}{l}\text { STb lingual } \\
\text { (Ormco; } n=10) \\
\text { versus labial } \\
\text { (Victory System, } \\
\text { 3M Unitek; } \\
n=10)\end{array}$ & $\begin{array}{l}\text { Selection based } \\
\text { on specific } \\
\text { criteria }\end{array}$ & $\begin{array}{l}\text { Anchorage loss } \\
\text { (amount of me- } \\
\text { sial movement } \\
\text { of the upper first } \\
\text { molar) measured } \\
\text { in cephalograms }\end{array}$ \\
\hline
\end{tabular}


Table 1. Continued

\begin{tabular}{|c|c|c|c|c|c|c|c|}
\hline Study & Subject group & Main objective & $\begin{array}{l}\text { Place of sample } \\
\text { collection }\end{array}$ & Study design & $\begin{array}{l}\text { Treatments tested } \\
\text { and sample size }\end{array}$ & $\begin{array}{l}\text { Method of } \\
\text { sample recruit- } \\
\text { ment }\end{array}$ & $\begin{array}{l}\text { Main type of col- } \\
\text { lected data }\end{array}$ \\
\hline $\begin{array}{l}\text { Soldanova et al., } \\
\text { Eur J Orthod } \\
2011(25)\end{array}$ & Clinical & $\begin{array}{l}\text { Changes in the } \\
\text { lower dental } \\
\text { arch with the } \\
\text { labial or the } \\
\text { lingual 2D } \\
\text { technique }\end{array}$ & $\begin{array}{l}\text { Prague, Czech } \\
\text { republic }\end{array}$ & $\begin{array}{l}\text { Prospective } \\
\text { CCT }\end{array}$ & $\begin{array}{l}\text { lingual 2D } \\
\text { (Forestadent; } \\
n=25 \text { ) versus } \\
\text { labial (Minitrim } \\
\text { Roth, Dentau- } \\
\text { rum; } n=25 \text { ) }\end{array}$ & $\begin{array}{l}\text { Selection based } \\
\text { on specific } \\
\text { criteria }\end{array}$ & $\begin{array}{l}\text { Cephalometric } \\
\text { measurements } \\
\text { and images of } \\
\text { dental casts } \\
\text { obtained pre } \\
\text { and post- } \\
\text { treatment }\end{array}$ \\
\hline $\begin{array}{l}\text { van der Veen } \\
\text { et al., Eur J Oral } \\
\text { Sci } 2010(6)\end{array}$ & Clinical & $\begin{array}{l}\text { Caries incidence } \\
\text { after treatment } \\
\text { with lingual or } \\
\text { labial appliances }\end{array}$ & $\begin{array}{l}\text { Bad Essen, Ger- } \\
\text { many }\end{array}$ & $\begin{array}{l}\text { RCT } \\
\text { (split mouth) }\end{array}$ & $\begin{array}{l}\text { Incognito lingual } \\
(n=14) \text { versus } \\
\text { labial (Orthos, } \\
\text { Ormco; } n=14)\end{array}$ & $\begin{array}{l}\text { Consecutive } \\
\text { selection based } \\
\text { on specific } \\
\text { criteria }\end{array}$ & $\begin{array}{l}\text { White spot caries } \\
\text { lesions measured } \\
\text { at white light } \\
\text { photographs } \\
\text { and quantitative } \\
\text { light-induced } \\
\text { fluorescence } \\
\text { images pre and } \\
\text { post-treatment }\end{array}$ \\
\hline $\begin{array}{l}\text { Beyling et al., } \\
\text { Head Face Med } \\
2013(28)\end{array}$ & Clinical & $\begin{array}{l}\text { To test the } \\
\text { effect of the } \\
\text { addition of an } \\
\text { extra layer of } \\
\text { a hydrophilic } \\
\text { resin, during } \\
\text { bonding, in the } \\
\text { demineralization } \\
\text { beneath the lin- } \\
\text { gual bracket base }\end{array}$ & $\begin{array}{l}\text { Bad Essen, } \\
\text { Germany }\end{array}$ & $\begin{array}{l}\text { Retrospective } \\
\text { case series }\end{array}$ & $\begin{array}{l}\text { Incognito lingual } \\
\text { bonded conven- } \\
\text { tionally }(n=20) \\
\text { versus bonded } \\
\text { with an extra } \\
\text { resin layer } \\
(n=20)\end{array}$ & $\begin{array}{l}\text { Consecutive } \\
\text { selection based } \\
\text { on specific } \\
\text { criteria }\end{array}$ & $\begin{array}{l}\text { Sub bracket le- } \\
\text { sions measured at } \\
\text { standardized pho- } \\
\text { tographs, pre and } \\
\text { post-treatment, in } \\
\text { the six maxillary } \\
\text { anterior teeth }\end{array}$ \\
\hline $\begin{array}{l}\text { Deguchi et al., } \\
\text { Angle Orthod } \\
2015(31)\end{array}$ & Clinical & $\begin{array}{l}\text { Differences in } \\
\text { cephalometric } \\
\text { values, root } \\
\text { resorption, } \\
\text { occlusal indices, } \\
\text { and functional } \\
\text { aspects, between } \\
\text { labial and lingual } \\
\text { treatment }\end{array}$ & Japan & $\begin{array}{l}\text { Retrospective } \\
\text { case series }\end{array}$ & $\begin{array}{l}\text { STb lingual } \\
(\text { Ormco })(n=24) \\
\text { versus labial } \\
(n=25)\end{array}$ & $\begin{array}{l}\text { Consecutive } \\
\text { selection based } \\
\text { on specific } \\
\text { criteria }\end{array}$ & $\begin{array}{l}\text { Cephalometric } \\
\text { values, degree of } \\
\text { root resorption, } \\
\text { PAR, objective } \\
\text { grading system } \\
\text { (OGS), and func- } \\
\text { tional evaluation } \\
\text { pre and post- } \\
\text { treatment }\end{array}$ \\
\hline $\begin{array}{l}\text { Ziebura et al., } \\
\text { Am J Orthod } \\
\text { Dentofacial Or- } \\
\text { thop } 2014 \text { (32) }\end{array}$ & Clinical & $\begin{array}{l}\text { To compare } \\
\text { frequency and } \\
\text { position of bond } \\
\text { failures in } \\
\text { patients treated } \\
\text { with lingual or } \\
\text { buccal } \\
\text { appliances }\end{array}$ & $\begin{array}{l}\text { Munster, } \\
\text { Germany }\end{array}$ & $\begin{array}{l}\text { Retrospective } \\
\text { case series }\end{array}$ & $\begin{array}{l}\text { Incognito lingual } \\
(n=59) \text { versus } \\
\text { Mini Diamond } \\
\text { Brackets/Accent } \\
\text { Molar Tubes } \\
\text { (Ormco) labial } \\
(n=44)\end{array}$ & $\begin{array}{l}\text { Selection based } \\
\text { on specific } \\
\text { criteria }\end{array}$ & $\begin{array}{l}\text { Number and posi- } \\
\text { tion of lost brack- } \\
\text { ets in the first year } \\
\text { of treatment }\end{array}$ \\
\hline $\begin{array}{l}\text { Knösel et al., } \\
\text { Head Face Med } \\
2014(18)\end{array}$ & Clinical & $\begin{array}{l}\text { To compare } \\
\text { treatment dura- } \\
\text { tion with two } \\
\text { types of } \\
\text { customized } \\
\text { lingual } \\
\text { appliances }\end{array}$ & $\begin{array}{l}\text { Bad Essen, } \\
\text { Germany }\end{array}$ & $\begin{array}{l}\text { Retrospective ca } \\
\text { series }\end{array}$ & $\begin{array}{l}\text { Incognito } \\
\text { lingual (3M } \\
\text { Unitek) } \\
(n=220) \text { versus } \\
\text { WIN lingual } \\
\text { (DW LingualSys- } \\
\text { tems) ( } n=156)\end{array}$ & $\begin{array}{l}\text { Selection based } \\
\text { on specific } \\
\text { criteria }\end{array}$ & $\begin{array}{l}\text { Treatment } \\
\text { duration }\end{array}$ \\
\hline $\begin{array}{l}\text { Demling et al., } \\
\text { Angle Orthod } \\
2010(26)\end{array}$ & $\begin{array}{l}\text { Periodontal } \\
\text { health }\end{array}$ & $\begin{array}{l}\text { Short-term } \\
\text { effect of lingual } \\
\text { appliances on } \\
\text { periodontal } \\
\text { and microbial } \\
\text { parameters }\end{array}$ & $\begin{array}{l}\text { Hannover, } \\
\text { Germany }\end{array}$ & $\begin{array}{l}\text { Prospective } \\
\text { CCT (control: } \\
\text { maxilla and } \\
\text { buccal sites) }\end{array}$ & $\begin{array}{l}\text { Incognito lingual } \\
\text { versus no appli- } \\
\text { ances ( } n=20 ; \\
\text { split mouth) }\end{array}$ & $\begin{array}{l}\text { Consecutive } \\
\text { selection based } \\
\text { on specific } \\
\text { criteria }\end{array}$ & $\begin{array}{l}\text { Clinical } \\
\text { periodontal } \\
\text { evaluation and } \\
\text { microbial analy- } \\
\text { sis before and } \\
4 \text { weeks after } \\
\text { bonding }\end{array}$ \\
\hline
\end{tabular}


Table 1. Continued

\begin{tabular}{|c|c|c|c|c|c|c|c|}
\hline Study & Subject group & Main objective & $\begin{array}{l}\text { Place of sample } \\
\text { collection }\end{array}$ & Study design & $\begin{array}{l}\text { Treatments tested } \\
\text { and sample size }\end{array}$ & $\begin{array}{l}\text { Method of } \\
\text { sample recruit- } \\
\text { ment }\end{array}$ & $\begin{array}{l}\text { Main type of col- } \\
\text { lected data }\end{array}$ \\
\hline $\begin{array}{l}\text { Miethke and } \\
\text { Brauner, J } \\
\text { Orofac Orthop } \\
2007(27)\end{array}$ & $\begin{array}{l}\text { Periodontal } \\
\text { health }\end{array}$ & $\begin{array}{l}\text { Periodontal } \\
\text { health of patients } \\
\text { treated with } \\
\text { Invisalign or } \\
\text { lingual } \\
\text { appliances }\end{array}$ & Berlin, Germany & $\begin{array}{l}\text { Prospective CCT } \\
\text { (control: second, } \\
\text { fourth quadrant) }\end{array}$ & $\begin{array}{l}\text { Ormco } 7 \text { gen } \\
\text { lingual }(n=30) \\
\text { versus Invisalign } \\
(n=30)\end{array}$ & $\begin{array}{l}\text { Consecutive } \\
\text { selection based } \\
\text { on specific } \\
\text { criteria }\end{array}$ & $\begin{array}{l}\text { Clinical peri- } \\
\text { odontal evaluation } \\
\text { after at least } \\
6 \text { months during } \\
\text { treatment at three } \\
\text { consecutive ap- } \\
\text { pointments ( } 3-4 \\
\text { weeks interval) }\end{array}$ \\
\hline
\end{tabular}

Table 2. Results of individual studies, quality assessment, and synthesis of results.

\begin{tabular}{|c|c|c|c|c|c|}
\hline Study & Subject group & $\begin{array}{l}\text { Definition of pre-speci- } \\
\text { fied main outcome }\end{array}$ & Summary outcome data & Additional outcomes & Quality assessment* \\
\hline $\begin{array}{l}\text { Grauer and Prof- } \\
\text { fit, Am J Orthod } \\
\text { Dentofacial Orthop } \\
2011 \text { (19) }\end{array}$ & Accuracy & $\begin{array}{l}\text { Level of accuracy and } \\
\text { effect of age, gender, } \\
\text { crowding, overbite, } \\
\text { overjet, ANB, days } \\
\text { in treatment, days in } \\
\text { slot-filling wire, Class II } \\
\text { elastics, vertical elastics, } \\
\text { interproximal reduction, }\end{array}$ & $\begin{array}{l}\text { In most cases, anterior } \\
\text { teeth were positioned } \\
\text { within } 1 \mathrm{~mm} \text { and } \\
\text { within } 4^{\circ} \text { of their planned } \\
\text { positions; differences } \\
\text { increased from ante- } \\
\text { rior to posterior; highly } \\
\text { significant differences in }\end{array}$ & $\begin{array}{l}\text { Various parameters } \\
\text { were statistically related } \\
\text { to the amount of rota- } \\
\text { tional and translational } \\
\text { discrepancy, but each of } \\
\text { these factors explained } \\
\text { only a small amount of } \\
\text { the total discrepancy }\end{array}$ & Unclear risk \\
\hline
\end{tabular}
rebondings, jaw, and all discrepancies except tooth type

tooth long-axial rotation

for the maxilla versus the mandible, and in all parameters for tooth type Mean deviations of set-up

Pauls AH, J Orofac Accuracy Orthop 2010 (20)
Level of accuracy and effect of age, jaw, various finishing wires, bracket generation, original front tooth axial position, change in the front tooth inclination during lingual treatment, type of tooth, type of scanner
Thalheim and

Swestka-Polly, Inf Orthod Kieferorthop 2008 (21)

Lossdörfer et al., J Orofac Orthop 2013

(29)
Accuracy Effect of lingual treatment on lower intercanine distance

Accuracy

Changes in lower incisor inclination during treatment and differences between set-up and treatment result from end result were: tip

(UJ/upper jaw $5.53^{\circ}$; LJ/

lower jaw $\left.5.72^{\circ}\right)$, torque (UJ 5.16 ${ }^{\circ}$; LJ 5.23 ${ }^{\circ}$, supra/infraposition (UJ $0.89 \mathrm{~mm}$; LJ $0.97 \mathrm{~mm}$ ), rotation (UJ $5.82^{\circ}$;

LJ $5.40^{\circ}$ ), in/out (UJ

$1.19 \mathrm{~mm}$; LJ $1.07 \mathrm{~mm}$ ) and anterior/posterior position (UJ $1.04 \mathrm{~mm}$; LJ $1.00 \mathrm{~mm}$ ); significant difference between jaws in the antero-posterior position only

Difference in intercanine distance of set-up versus final result $0.44 \pm 0.29 \mathrm{~mm}$ Difference of clinically achieved versus planned inclinations was $5.89 \pm 5.43^{\circ}$, after correcting for changes in occlusal plane inclination. It was $3.75 \pm 3.06^{\circ}$ versus $8.59 \pm 6.58^{\circ}$ for full-size versus undersized finishing archwires and $7.88 \pm 6.36^{\circ}$ versus $4.65 \pm 4.48^{\circ}$ for extraction versus non-extraction cases
Significant differences for final archwires and different bracket generations and tooth types; the upper central incisors yielded the lowest values after the lower front teeth with deviations in rotation less than $4.5^{\circ}$ and in translation less than $0.40 \mathrm{~mm}$; from anterior to posterior, feasibility decreased by approx. $2^{\circ}$ and $1 \mathrm{~mm}$, with the second molars showing the poorest values Difference in intercanine distance of initial versus final result $1.85 \pm 1.58 \mathrm{~mm}$ 21 central incisor apices were located in the middle symphyseal third at baseline. Only 5 remained at debonding, whereas the other 16 moved to the lingual third $(P<0.001)$. A total of 13 apices were located in the lingual third at baseline and retained this position in all but one patient
High risk

High risk

High risk 
Table 2. Continued

\begin{tabular}{|c|c|c|c|c|c|}
\hline Study & Subject group & $\begin{array}{l}\text { Definition of pre-speci- } \\
\text { fied main outcome }\end{array}$ & Summary outcome data & Additional outcomes & Quality assessment* \\
\hline $\begin{array}{l}\text { Wiechmann et al., } \\
\text { Head Face Med } \\
2010(22)\end{array}$ & $\begin{array}{l}\text { Accuracy and } \\
\text { clinical }\end{array}$ & $\begin{array}{l}\text { Changes in lower inci- } \\
\text { sor inclination during } \\
\text { lingual + Herbst treat- } \\
\text { ment and differences } \\
\text { between set-up and } \\
\text { treatment result }\end{array}$ & $\begin{array}{l}\text { Planned incisor inclina- } \\
\text { tion: }-16.5^{\circ} \text { to } 5.8^{\circ} \text {; dif- } \\
\text { ference between planned } \\
\text { and final incisor rotations } \\
\text { was } 2.2^{\circ} \pm 1.0^{\circ}(P>0.05)\end{array}$ & - & High risk \\
\hline $\begin{array}{l}\text { Smith C, dissertation } \\
2010(23)\end{array}$ & $\begin{array}{l}\text { Accuracy and } \\
\text { clinical }\end{array}$ & $\begin{array}{l}\text { PAR score in lingual } \\
\text { and labial treatment }\end{array}$ & $\begin{array}{l}\text { treatment time: lingual } \\
22.35 \pm 5.19 \mathrm{~m} \text {, labial } \\
22.35 \pm 5.15 \mathrm{~m}(\mathrm{~ns}) \text {; total } \\
\text { reduction in PAR score: } \\
\text { lingual } 15.24 \pm 7.71 \text {, labi- } \\
\text { al } 18.27 \pm 11.15(\mathrm{~ns}) \text {; per- } \\
\text { centage of PAR reduction: } \\
\text { lingual } 77.51 \pm 23.11 \% \text {, } \\
\text { labial } 79.83 \pm 19.34 \% \\
\text { (ns); diagnostic set-up } \\
(0.4) \text { versus post-tx }(4.5) \\
\text { total weighted PAR } \\
(P<0.05)\end{array}$ & $\begin{array}{l}\text { There was no significant } \\
\text { difference between } \\
\text { any of the individual } \\
\text { PAR components and } \\
\text { in total weighted PAR } \\
\text { scores in the two groups } \\
\text { pre-treatment; the only } \\
\text { difference post-treat- } \\
\text { ment was in overbite } \\
(P<0.05 \text {; labial mean } \\
\text { PAR = } 0 \text {; lingual = 0.29) }\end{array}$ & High risk \\
\hline $\begin{array}{l}\text { Geron et al., Angle } \\
\text { Orthod } 2003 \text { (24) }\end{array}$ & Clinical & $\begin{array}{l}\text { Anchorage loss (amount } \\
\text { of mesial movement of } \\
\text { the upper first molar) } \\
\text { during lingual treatment }\end{array}$ & $\begin{array}{l}\text { Cephalograms: lin- } \\
\text { gual }=1.84 \pm 1.4 \mathrm{~mm}, \\
\text { labial }=3.0 \pm 1.4 \mathrm{~mm} \\
(P<0.05) ; \text { casts: } \\
\text { lingual }=2.4 \pm 1.9, \text { la- } \\
\text { bial }=3.9 \pm 2.7(\mathrm{~ns})\end{array}$ & - & High risk \\
\hline $\begin{array}{l}\text { Venkatesh et al., } \\
\text { APOS Trends Or- } \\
\text { thod } 2015(30)\end{array}$ & Clinical & $\begin{array}{l}\text { Anchorage loss in first } \\
\text { premolar extraction } \\
\text { cases (mesial movement } \\
\text { of the upper first molar) }\end{array}$ & $\begin{array}{l}\text { Lingual: } 1.24 \pm 0.17 \mathrm{~mm} \text {, } \\
\text { labial: } 2.06 \pm 0.39 \mathrm{~mm} \\
(P=0.001)\end{array}$ & - & High risk \\
\hline $\begin{array}{l}\text { Soldanova et al., Eur } \\
\text { J Orthod } 2011(25)\end{array}$ & Clinical & $\begin{array}{l}\text { Cephalometric and cast } \\
\text { measurements in lingual } \\
\text { and labial treatment }\end{array}$ & $\begin{array}{l}\text { Significant difference in } \\
\text { the position of incisors } \\
\text { relative to A-Po (lingual: } \\
1.0 \pm 0.5 \mathrm{~mm} \text {; labial: } \\
0.0 \pm 1.5 \mathrm{~mm} P<0.05 \text { ); no } \\
\text { other differences in posi- } \\
\text { tion of incisors, canines } \\
\text { or molars }\end{array}$ & $\begin{array}{l}\text { Active treatment time: } \\
\text { lingual: } 14.6 \pm 6.98 \mathrm{~m} \\
\text { labial: } 15.44 \pm 7.38 \mathrm{~m}\end{array}$ & High risk \\
\hline $\begin{array}{l}\text { van der Veen et al., } \\
\text { Eur J Oral Sci } 2010 \\
(6)\end{array}$ & Clinical & $\begin{array}{l}\text { Presence/absence or } \\
\text { progress of lesions in } \\
\text { lingual and labial treat- } \\
\text { ment }\end{array}$ & $\begin{array}{l}\text { The number of caries that } \\
\text { formed (buccal: } n=16 \text {, } \\
\text { lingual: } n=1 \text { ) or pro- } \\
\text { gressed (buccal: } n=21 \text {, } \\
\text { lingual: } n=7 \text { ) was higher } \\
\text { in buccal compared to } \\
\text { lingual lesions ( } P=0.01 \text { ); } \\
\text { the overall increase in car- } \\
\text { ies extent/total lesion area } \\
\text { was } 10.6 \text { times higher } \\
\text { on buccal surfaces in a } \\
\text { subject than on lingual } \\
\text { surfaces }(P<0.05)\end{array}$ & $\begin{array}{l}\text { The number of new } \\
\text { lesions developing or } \\
\text { progressing on brack- } \\
\text { eted buccal surfaces } \\
\text { was } 4.8 \text { times higher } \\
\text { and the caries extent, or } \\
\text { integrated fluorescence } \\
\text { loss, was } 10.6 \text { times } \\
\text { higher than in lingual } \\
\text { surfaces }\end{array}$ & High risk \\
\hline $\begin{array}{l}\text { Beyling et al., Head } \\
\text { Face Med } 2013 \text { (28) }\end{array}$ & Clinical & $\begin{array}{l}\text { Incidence of deminerali- } \\
\text { zation beneath the lin- } \\
\text { gual bracket base at the } \\
\text { end of treatment with } \\
\text { two bonding protocols }\end{array}$ & $\begin{array}{l}\text { With standard indirect } \\
\text { chemical cure bonding, } 18 \\
\text { lesions occurred in } 120 \\
\text { surfaces }(15 \%) \text {. With the } \\
\text { addition of an extra layer } \\
\text { of a hydrophilic resin, } 6 \\
\text { lesions occurred in } 120 \\
\text { surfaces }(5 \%), P=0.01\end{array}$ & $\begin{array}{l}\text { Gender and age were } \\
\text { not significantly related } \\
\text { to the development of } \\
\text { new lesions }\end{array}$ & High risk \\
\hline
\end{tabular}


Table 2. Continued

\begin{tabular}{|c|c|c|c|c|c|}
\hline Study & Subject group & $\begin{array}{l}\text { Definition of pre-speci- } \\
\text { fied main outcome }\end{array}$ & Summary outcome data & Additional outcomes & Quality assessment* \\
\hline $\begin{array}{l}\text { Deguchi et al., Angle } \\
\text { Orthod } 2015 \text { (31) }\end{array}$ & Clinical & $\begin{array}{l}\text { Cephalometric values, } \\
\text { degree of root resorp- } \\
\text { tion, PAR, OGS, and } \\
\text { functional evaluation } \\
\text { in lingual and labial } \\
\text { treatment }\end{array}$ & $\begin{array}{l}\text { Pre-treatment PAR, } \\
\text { labial: } 25.0 \pm 9.6 \text {, lingual: } \\
28.0 \pm 7.2 \text { (ns); post- } \\
\text { treatment PAR, labial: } \\
4.0 \pm 2.2 \text {, lingual: } 4.2 \pm 2.2 \\
\text { (ns). Pre-treatment cepha- } \\
\text { lometric measurements } \\
\text { (ns). Post-treatment only } \\
\text { interincisal angle (T0-T1, } \\
\text { labial: } 11.2 \pm 11.6 \text {; lingual, } \\
17.9 \pm 8.9, P<0.05 \text { ). } \\
\text { Root resorption, la- } \\
\text { bial: } 1.1 \pm 0.5 \text { mm, lingual: } \\
1.3 \pm 0.6 \text { mm (ns). Jaw } \\
\text { movements increased in the } \\
\text { same way in both groups }\end{array}$ & $\begin{array}{l}\text { Average treatment time, } \\
\text { labial: } 29.4 \pm 5.6 \mathrm{~m} \text {, lin- } \\
\text { gual: } 32.5 \pm 6.7 \mathrm{~m}(\mathrm{~ns})\end{array}$ & High risk \\
\hline $\begin{array}{l}\text { Ziebura et al., Am J } \\
\text { Orthod Dentofacial } \\
\text { Orthop } 2014(32)\end{array}$ & Clinical & $\begin{array}{l}\text { Number and positions } \\
\text { of lost brackets in the } \\
\text { first year of lingual and } \\
\text { labial treatment }\end{array}$ & $\begin{array}{l}\text { Bond failures per patient } \\
\text { lingual: } 2.63 \pm 2.77 \\
\text { buccal: } 2.61 \pm 3.41 \\
(P=0.428)\end{array}$ & $\begin{array}{l}\text { Molar brackets failed } \\
\text { more than premolar } \\
(P<0.05) \text {; premolar } \\
\text { brackets more than } \\
\text { canine and incisor } \\
(P<0.05) \text {. Tendency } \\
\text { for more failures in } \\
\text { the mandible (lingual: } \\
P=0.069 \text {; buccal: } \\
P=0.036 .) \text { Occlusal } \\
\text { pads in lingual lowered } \\
\text { failures in molars, but } \\
\text { not in premolars }\end{array}$ & High risk \\
\hline $\begin{array}{l}\text { Knösel et al., Head } \\
\text { Face Med } 2014 \text { (18) }\end{array}$ & Clinical & $\begin{array}{l}\text { Treatment duration } \\
\text { with two types of } \\
\text { customized lingual ap- } \\
\text { pliances }\end{array}$ & $\begin{array}{l}\text { Treatment duration } \\
\text { WIN (Severity1: } 17.96 \mathrm{~m} \text {; } \\
\text { S2: } 20.49 \mathrm{~m} \text { ); Incognito } \\
(\mathrm{S} 1: 22.7 \mathrm{~m} \text {; S2: } 29.79 \mathrm{~m}) \\
P<0.001\end{array}$ & $\begin{array}{l}\text { Significant influence } \\
\text { of 'appliance type', } \\
\text { and 'case severity' on } \\
\text { treatment duration, not } \\
\text { dependent on each other; } \\
\text { no difference in frequen- } \\
\text { cies of bracket losses }\end{array}$ & High risk \\
\hline $\begin{array}{l}\text { Demling et al., Angle } \\
\text { Orthod } 2010(26)\end{array}$ & $\begin{array}{l}\text { Periodontal } \\
\text { health }\end{array}$ & $\begin{array}{l}\text { Changes in periodontal } \\
\text { and microbial param- } \\
\text { eters after } 1 \text { month of } \\
\text { lingual treatment on the } \\
\text { lower arch }\end{array}$ & $\begin{array}{l}\text { Mandible lingual } \\
\text { side PI: } \mathrm{t} 0=0.3 \pm 0.3, \\
\mathrm{t} 1=1.0 \pm 0.7(P=0.001) \\
\text { BOP: } \mathrm{t} 0=23.4 \pm 22.5, \\
\mathrm{t} 1=46.2 \pm 23.5 \\
(P=0.001) ; \mathrm{PPD}: \\
\mathrm{t} 0=2.1 \pm 0.4, \\
\mathrm{t} 1=2.2 \pm 0.3(\mathrm{~ns}) ; \text { preva- } \\
\text { lence of Aa: } \mathrm{t} 0=25 \%, \\
\mathrm{t} 1=35 \% ; \text { prevalence of } \\
\text { Pg: } \mathrm{t} 0=5 \%, \mathrm{t} 1=5 \%\end{array}$ & $\begin{array}{l}\text { No difference in control } \\
\text { sites in any of the tested } \\
\text { variables between } t 0 \\
\text { and } t 1\end{array}$ & Unclear risk \\
\hline $\begin{array}{l}\text { Miethke and } \\
\text { Brauner, J Orofac } \\
\text { Orthop } 2007 \text { (27) }\end{array}$ & $\begin{array}{l}\text { Periodontal } \\
\text { health }\end{array}$ & $\begin{array}{l}\text { Difference in gingival } \\
\text { index (GI), papillary } \\
\text { bleeding index (PBI). } \\
\text { Plaque index (PI), sulcus } \\
\text { probing depth (SPD) } \\
\text { between lingual and } \\
\text { Invisalign treatment at } \\
\text { three consecutive ap- } \\
\text { pointments (T1, T2, T3) }\end{array}$ & $\begin{array}{l}\text { GI Invisalign/GI lingual } \\
\text { Median T1: } 0.68 / 1.13 \\
\text { Median T2: } 0.56 / 1.02 \\
\text { Median T3: } 0.34 / 1.00 \\
\text { PBI Invisalign/PBI lingual } \\
\text { Median T1: } 0.21 / 0.57 \\
\text { Median T2: } 0.19 / 0.55 \\
\text { Median T3: } 0.11 / 0.58 \\
\text { PI Invisalign/PI lingual } \\
\text { Median T1: } 0.31 / 0.79 \\
\text { Median T2: } 0.34 / 0.96 \\
\text { Median T3: } 0.19 / 0.83 \\
\text { The SPD of approximately } \\
\text { 2.5 mm was similar in both } \\
\text { groups in all time points }\end{array}$ & $\begin{array}{l}\text { All the indices improved } \\
\text { significantly between the } \\
\text { first and third assess- } \\
\text { ments in the Invisalign } \\
\text { patients, while they } \\
\text { were significantly worse } \\
\text { in lingual treatment }\end{array}$ & Unclear risk \\
\hline
\end{tabular}

*Low risk, unclear risk, or high risk of bias study; ns, non-significant. 
Table 3. Risk of bias summary for included retrospective studies.

\begin{tabular}{|c|c|c|c|c|c|c|c|c|c|c|c|}
\hline & $\begin{array}{l}\text { Grauer } \\
\text { and Proffit } \\
(19)\end{array}$ & Pauls (20) & $\begin{array}{l}\text { Thalheim } \\
\text { and Swestka- } \\
\text { Polly }(21)\end{array}$ & $\begin{array}{l}\text { Lossdörfer } \\
\text { et al. (29) }\end{array}$ & $\begin{array}{l}\text { Wiechmann } \\
\text { et al. }(22)\end{array}$ & Smith (23) & $\begin{array}{l}\text { Geron } \\
\text { et al. } \\
(24)\end{array}$ & $\begin{array}{l}\text { Beyling } \\
\text { et al. } \\
(28)\end{array}$ & $\begin{array}{l}\text { Deguchi } \\
\text { et al. } \\
(31)\end{array}$ & $\begin{array}{l}\text { Ziebura } \\
\text { et al. } \\
(32)\end{array}$ & $\begin{array}{l}\text { Knösel } \\
\text { et al. } \\
(18)\end{array}$ \\
\hline $\begin{array}{l}\text { Representative sam- } \\
\text { ple of adequate size }\end{array}$ & Unclear & Unclear & Unclear & High & High & Unclear & High & Unclear & Unclear & Unclear & High \\
\hline $\begin{array}{l}\text { Was there a } \\
\text { comparison? What } \\
\text { kind? }\end{array}$ & Low & High & Unclear & Unclear & Unclear & High & High & Low & High & High & High \\
\hline $\begin{array}{l}\text { How participants } \\
\text { were allocated to } \\
\text { groups? }\end{array}$ & Unclear & High & High & Unclear & Unclear & High & Unclear & Unclear & Unclear & Unclear & Unclear \\
\hline $\begin{array}{l}\text { Which parts of the } \\
\text { study were prospec- } \\
\text { tive? }\end{array}$ & Unclear & Unclear & Unclear & Unclear & Unclear & Unclear & Unclear & Unclear & Unclear & Unclear & High \\
\hline $\begin{array}{l}\text { On what variables } \\
\text { was comparabil- } \\
\text { ity between groups } \\
\text { assessed? }\end{array}$ & Low & Low & Low & Low & Low & Unclear & High & High & Unclear & High & High \\
\hline $\begin{array}{l}\text { Incomplete outcome } \\
\text { reporting }\end{array}$ & Low & Unclear & Low & Low & Low & Low & Unclear & Low & Unclear & Low & Low \\
\hline $\begin{array}{l}\text { Inclusion criteria ex- } \\
\text { plicitly described }\end{array}$ & Unclear & High & High & High & Unclear & Unclear & High & Low & Low & Unclear & Unclear \\
\hline $\begin{array}{l}\text { Adjusting for con- } \\
\text { founders }\end{array}$ & Low & High & Unclear & Unclear & Unclear & High & High & High & Unclear & High & High \\
\hline $\begin{array}{l}\text { Description of } \\
\text { potential biases }\end{array}$ & Unclear & High & High & High & High & High & High & High & High & Unclear & Unclear \\
\hline $\begin{array}{l}\text { Blinding of the } \\
\text { assessor }\end{array}$ & Unclear & High & Unclear & Unclear & Unclear & Low & High & Low & High & Low & Low \\
\hline $\begin{array}{l}\text { Reporting of drop- } \\
\text { outs/excluded cases }\end{array}$ & Unclear & High & High & High & Unclear & Unclear & Unclear & Unclear & Low & High & Unclear \\
\hline $\begin{array}{l}\text { Reporting of follow- } \\
\text { up }\end{array}$ & Low & Low & Low & Low & Low & Low & Unclear & Low & Low & Low & Low \\
\hline Overall & Unclear & High & High & High & High & High & High & High & High & High & High \\
\hline
\end{tabular}

In each criterion, each study was classified as having low, unclear, or high risk of bias. Overall, studies with at least one high risk are considered high risk of bias, studies with at least one unclear risk are considered of unclear risk of bias, while studies with low risk only low risk of bias.

duration was significantly smaller with WIN compared to Incognito system (18). The results of these investigations, however, have to be interpreted taken into account the possibility of the influence of the various biases on the study outcomes.

The third subject group included two prospective CCTs that investigated the effect of lingual orthodontic treatment on various periodontal parameters. The first study tested, in a split-mouth design, the short-term influence of Incognito lingual appliances on various clinical periodontal and microbial indices and showed a worsening of plaque index and bleeding on probing in the bonded sites, while no significant difference was detected on probing depth and periodontopathogenic bacteria (26). The other study tested the effect of Ormco seventh generation lingual treatment as well as Invisalign treatment on clinical periodontal parameters. All the indices apart from probing depth improved significantly between assessments in the Invisalign patients, while they were significantly worse in lingual treatment in all time points (27). Concerning the interpretation of the findings of these two studies, however, it must be taken into consideration that both are single nonrandomized studies with unclear risk of bias.

\section{Limitations}

There is a shortage of large, high-quality prospective clinical trials investigating clinical outcomes and effects of lingual orthodontic treatment (only one RCT was available). Thus, the majority of the included studies had a retrospective design and the risk of bias was high. An assessment of high risk of bias does not necessarily mean that the study results are biased; it means that the suspicion of biased results is higher compared to those of a study classified at low risk of bias.

In most cases, no synthesis of studies was feasible since there was only a single study on each subject. In the presence of more than one study on a subject, grouping and/or synthesis of results and conclusions was not feasible due to the clinical heterogeneity of the included studies (e.g. different bracket systems are tested).

Language restrictions might be an additional limitation in the present systematic review.

\section{Conclusions}

This systematic review showed encouraging results on the clinical outcome of lingual orthodontic treatment, especially in regards to the achievement of individualized treatment goals and the decreased risk of decalcifications on the bonded surfaces of the teeth. However, additional well-designed prospective clinical trials with large samples are needed to confirm those findings. Several aspects of lingual orthodontic treatment were difficult to be conclusively evaluated due to the study design, the heterogeneity, the small samples, and the high risk of bias seen in the majority of the included studies.

\section{Supplementary material}

Supplementary material is available at European Journal of Orthodontics online. 


\section{References}

1. Ziuchkovski, J.P., Fields, H.W., Johnston, W.M. and Lindsey, D.T. (2008) Assessment of perceived orthodontic appliance attractiveness. American Journal of Orthodontics and Dentofacial Orthopedics, 133(4 Suppl.), S68-78.

2. Rosvall, M.D., Fields, H.W., Ziuchkovski, J., Rosenstiel, S.F. and Johnston, W.M. (2009) Attractiveness, acceptability, and value of orthodontic appliances. American Journal of Orthodontics and Dentofacial Orthopedics, 135, 276 e1-12.

3. Gkantidis, N., Zinelis, S., Karamolegkou, M., Eliades, T. and Topouzelis, N. (2012) Comparative assessment of clinical performance of esthetic bracket materials. The Angle Orthodontist, 82, 691-697.

4. Singh, P. and Cox, S. (2011) Lingual orthodontics: an overview. Dental Update, 38, 390-395.

5. Chan, E.K., McCrostie, S., Petocz, P. and Darendeliler, M.A. (2007) Profile of lingual orthodontic users in Australia. Australian Dental Journal, 52, 288-294.

6. van der Veen, M.H., Attin, R., Schwestka-Polly, R. and Wiechmann, D. (2010) Caries outcomes after orthodontic treatment with fixed appliances: do lingual brackets make a difference? European Journal of Oral Sciences, 118, 298-303.

7. Wiechmann, D., Rummel, V., Thalheim, A., Simon, J.S. and Wiechmann, L. (2003) Customized brackets and archwires for lingual orthodontic treatment. American Journal of Orthodontics and Dentofacial Orthopedics, $124,593-599$.

8. Long, H., Zhou, Y., Pyakurel, U., Liao, L., Jian, F., Xue, J., Ye, N., Yang, X., Wang, Y. and Lai, W. (2013) Comparison of adverse effects between lingual and labial orthodontic treatment. The Angle Orthodontist, 83, 1066-1073.

9. Noble, J., Hechter, F.J., Karaiskos, N.E., Lekic, N. and Wiltshire, W.A. (2009) Future practice plans of orthodontic residents in the United States. American Journal of Orthodontics and Dentofacial Orthopedics, 135, 357-360.

10. Banks, P., Elton, V., Jones, Y., Rice, P., Derwent, S. and Odondi, L. (2010) The use of fixed appliances in the UK: a survey of specialist orthodontists. Journal of Orthodontics 37: 43-55

11. Liberati, A., Altman, D.G., Tetzlaff, J., Mulrow, C., Gotzsche, P.C., Ioannidis J.P., Clarke, M., Devereaux, P.J., Kleijnen, J. and Moher, D. (2009) The PRISMA statement for reporting systematic reviews and meta-analyses of studies that evaluate health care interventions: explanation and elaboration. Journal of Clinical Epidemiology, 62, e1-34.

12. Moher, D., Liberati, A., Tetzlaff, J. and Altman, D.G. (2009) Preferred reporting items for systematic reviews and meta-analyses: the PRISMA statement. Journal of Clinical Epidemiology, 62, 1006-1012.

13. Stroup, D.F., Berlin, J.A., Morton, S.C., Olkin, I., Williamson, G.D., Rennie, D., Moher, D., Becker, B.J., Sipe, T.A. and Thacker, S.B. (2000) Meta-analysis of observational studies in epidemiology: a proposal for reporting. Meta-analysis Of Observational Studies in Epidemiology (MOOSE) group. JAMA, 283, 2008-2012.

14. Manchikanti L, Datta S, Smith H S, Hirsch J A. (2009) Evidence-based medicine, systematic reviews, and guidelines in interventional pain management: part 6. Systematic reviews and meta-analyses of observational studies. Pain Physician 12: 819-850.

15. Higgins, J.P. and Green, S. (2011) Cochrane Handbook for Systematic Reviews of Interventions Version 5.1.0. The Cochrane Collaboration, 2011. http://handbook.cochrane.org/ (1 March 2015, date last accessed).

16. Guyatt, G.H. et al.et al. (2013) GRADE guidelines: 13. Preparing summary of findings tables and evidence profiles-continuous outcomes. Journal of Clinical Epidemiology, 66, 173-183.

17. Higgins, J.P. et al.et al. (2011) The Cochrane Collaboration's tool for assessing risk of bias in randomised trials. BMJ, 343, d5928.
18. Knösel, M., Klang, E., Helms, H.J. and Wiechmann, D. (2014) Lingual orthodontic treatment duration: performance of two different completely customized multi-bracket appliances (Incognito and WIN) in groups with different treatment complexities. Head \& Face Medicine, 10, 46.

19. Grauer, D. and Proffit, W.R. (2011) Accuracy in tooth positioning with a fully customized lingual orthodontic appliance. American Journal of Orthodontics and Dentofacial Orthopedics, 40, 433-443.

20. Pauls, A.H. (2010) Therapeutic accuracy of individualized brackets in lingual orthodontics. Journal of Orofacial Orthopedics, 71, 348-361.

21. Thalheim, A. and Schwestka-Polly, R. (2008) Klinische Umsetzbarkeit eines Setups in der lingualen Orthodontie. Informationen aus Orthodontie und Kieferorthopädie, 40, 277-282.

22. Wiechmann, D., Schwestka-Polly, R., Pancherz, H., and Hohoff, A. (2010) Control of mandibular incisors with the combined Herbst and completely customized lingual appliance-a pilot study. Head \& Face Medicine, 6, 3.

23. Smith, C. (2010) A comparison of PAR scores and treatment time with iBraces ${ }^{\mathrm{TM}}$ versus labial braces. Master of Science in Oral Sciences Thesis, University of Illinois, Chicago.

24. Geron, S., Shpack, N., Kandos, S., Davidovitch, M. and Vardimon A.D. (2003) Anchorage loss-a multifactorial response. The Angle Orthodontist, $73,730-737$.

25. Soldanova, M., Leseticky, O., Komarkova, L., Dostalova, T., Smutny, V. and Spidlen, M. (2012) Effectiveness of treatment of adult patients with the straightwire technique and the lingual two-dimensional appliance. European Journal of Orthodontics, 34, 674-680.

26. Demling, A., Demling, C., Schwestka-Polly, R., Stiesch, M. and Heuer, W. (2010) Short-term influence of lingual orthodontic therapy on microbial parameters and periodontal status. A preliminary study. The Angle Orthodontist, 80, 480-484.

27. Miethke, R.R. and Brauner, K. (2007) A Comparison of the periodontal health of patients during treatment with the Invisalign system and with fixed lingual appliances. Journal of Orofacial Orthopedics, 68, 223231.

28. Beyling, F., Schwestka-Polly, R. and Wiechmann, D. (2013) Lingual orthodontics for children and adolescents: improvement of the indirect bonding protocol. Head \& Face Medicine, 9, 27.

29. Lossdorfer, S., Schwestka-Polly, R. and Wiechmann, D. (2013) Control of lower incisor inclination with a completely customized lingual appliance for dentoalveolar compensation of class III malocclusion. Journal of Orofacial Orthopedics, 74, 381-396.

30. Venkatesh, S., Rozario, J., Ganeshkar, S. and Ajmera, S. (2015) Comparative evaluation of sagittal anchorage loss in lingual and labial appliances during space closure: A pilot study. APOS Trends in Orthodontics, 5,33 .

31. Deguchi, T., Terao, F., Aonuma, T., Kataoka, T., Sugawara, Y., Yamashiro, T. and Takano-Yamamoto, T. (2015) Outcome assessment of lingual and labial appliances compared with cephalometric analysis, peer assessment rating, and objective grading system in Angle Class II extraction cases. The Angle Orthodontist, 85, 400-407.

32. Ziebura, T., Hohoff, A., Flieger, S. and Stamm, T. (2014) Accidental debondings: Buccal vs fully individualized lingual multibracket appliances. American Journal of Orthodontics and Dentofacial Orthopedics, 145, 649-654.

33. Moshkelgosha, V., Salahi, M. and Rostami, S. (2015) Evaluation of perceived acceptability, beauty and value of different orthodontic brackets. Journal of Dental Biomaterials, 2, 33-38.

34. Echarri P. (2006) (ed.) Revisiting the history of lingual orthodontics: a basis for the future. Seminars in Orthodontics, 12, 153-159.

35. Ling, P.H. (2005) Lingual orthodontics: history, misconceptions and clarification. Journal (Canadian Dental Association), 71, 99-102. 